Assoc. Prof. Tadeusz Przybyłowski, MD, PhD'

Prof. Waldemar Tomalak, MD, PhD'

Prof. Zenon Siergiejko, MD, $\mathrm{PhD}^{3}$

Prof. Dariusz Jastrzębski, MD, PhD ${ }^{4}$

Dr Marta Maskey-Warzęchowska, MD, PhD ${ }^{1}$

Assoc. Prof. Tomasz Piorunek, MD, PhD

Dr Emil Wojda, MD, PhD ${ }^{6}$

Assoc. Prof. Piotr Boros, MD, PhD ${ }^{7}$

'Department of Internal Medicine, Pneumonology and Allergology, Medical University of Warsaw, Poland

${ }^{2}$ Department of Physiopathology of the Respiratory System, Rabka-Zdrój Branch of the Institute of Tuberculosis and Lung Diseases, Poland ${ }^{3}$ Laboratory of Respiratory Diagnostics and Bronchoscopy, Medical University of Białystok, Poland

${ }^{4}$ Department of Lung Diseases and Tuberculosis, Medical University of Silesia, Poland

${ }^{5}$ Department of Pulmonology Allergology and Pulmonary Oncology, Poznań University of Medical Sciences, Poland

${ }^{6}$ Department of Lung Diseases, Institute of Tuberculosis and Lung Diseases, Warsaw, Poland

${ }^{7}$ Department of Physiopathology of the Respiratory System, Institute of Tuberculosis and Lung Diseases, Warsaw, Poland

Reviewers:

Prof. Ryszarda Chazan, MD, PhD

Prof. Władysław Pierzchała, MD, PhD

Prof. Wacław Droszcz, MD, PhD

Prof. Adam Antczak, MD, PhD

DOI: 10.5603/PiAP.2015.0048

\title{
Polish Respiratory Society guidelines for the methodology and interpretation of the 6 minute walk test (6MWT)
}

\section{CONTENTS}

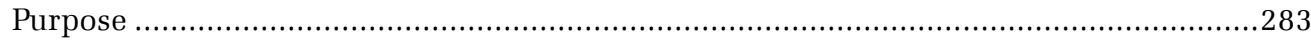

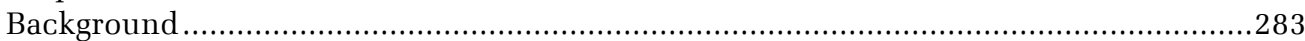

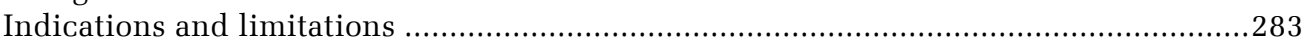

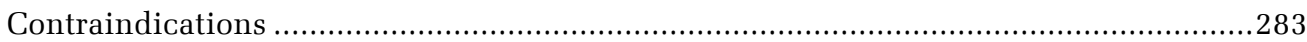

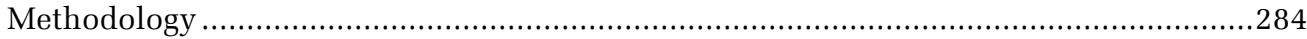

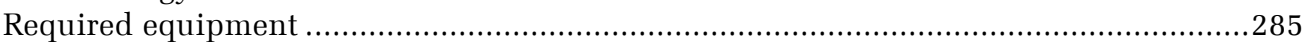

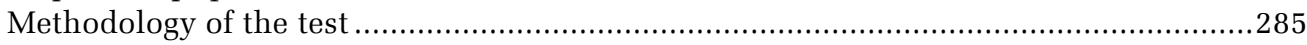

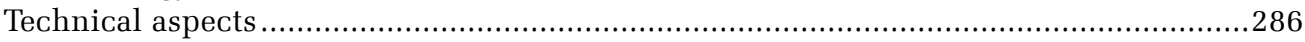

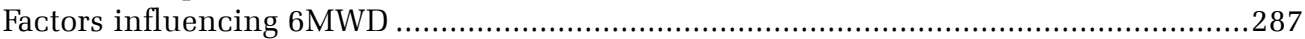

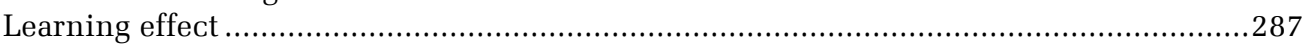

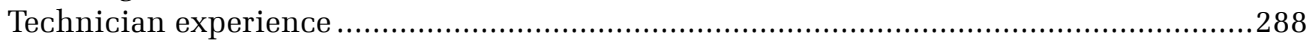

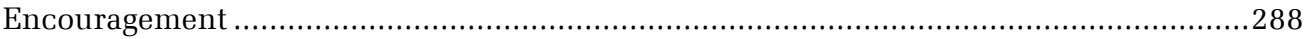

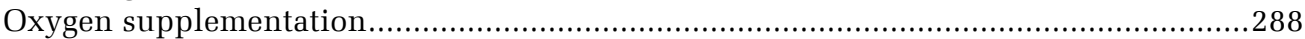

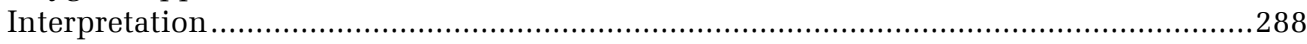

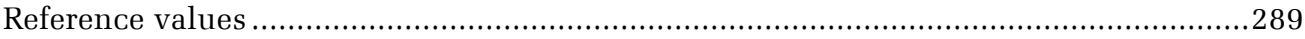

Single measurement interpretation — assessment of functional status .......................289

Changes in blood oxygen saturation .................................................................290

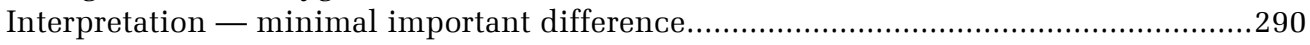

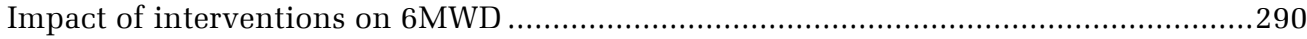

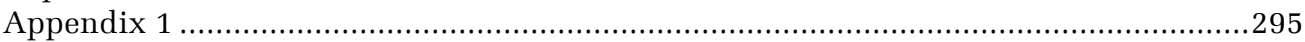

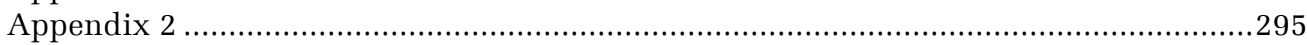

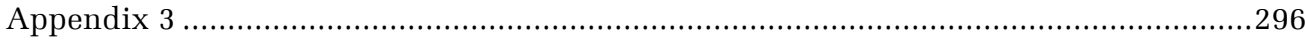

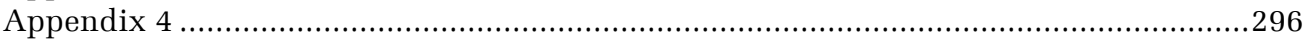

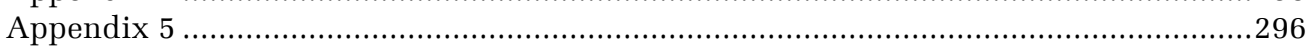




\section{Purpose}

This statement contains cohesive practical guidelines for the indications, contraindications, methodology and interpretation of 6 minute walk test (6MWT). The authors are convinced that these guidelines may also be helpful in the $\mathrm{Na}$ tional Health Fund (Narodowy Fundusz Zdrowia) reimbursement issues (procedure No 89.387 spirometry with 6 minute walk test).

The document has been prepared by the Polish Respiratory Society Task Force recruited from the members of the PRS Respiratory Physiopathology section in the form of a consensus statement.

\section{Background}

Disability related to progressive functional impairment is one of the most important consequences in chronic conditions, particularly in chronic cardiovascular and respiratory diseases. Exercise intolerance is a widely accepted measure of the degree of disability [1]. Thus, in many diseases, assessment of exercise tolerance is an important element in the evaluation of the patient.

Functional classifications may provide some information about the physical condition of the patient. The New York Heart Association (NYHA) classification is widely used in patients with heart failure [2], for patients with chronic obstructive pulmonary disease the Medical Research Council (MRC) dyspnea scale is recommended. [3]. Nevertheless, this is a subjective evaluation and in the majority of cases, objective measures are more important and have a higher value.

Cardiopulmonary exercise test is a complex test performed on a treadmill or cycle ergometer. Walk tests are a simple alternative method which also allow to assess exercise response [4]. 6 minute walk test is the most commonly used, however there are various test modalities which include different time durations (e.g. 12 minute walk test), fixed distance, step test or shuttle walk test [5].

$6 \mathrm{MWT}$ is currently widely used to evaluate functional capacity. It may more adequately reflect patient's activity than complex tests as the level of exercise is comparable to that performed on a daily basis [6]. The main advantage of simple exercise tests is that they do not require equipment and may thus be performed in most healthcare centers. However, they provide little information on the cause of limited exercise tolerance. Only when certain evident signs occur may the differentiation be possible, e.g. chest pain may indicate heart disease, while a decrease in oxygen saturation $\left(\mathrm{SpO}_{2}\right)$ strongly suggests a respiratory background.

\section{Indications and limitations}

According to the American Thoracic Society (ATS) the main indication for 6MWT is the assessment of response to medical interventions in patients with mild to moderate chronic respiratory or cardiovascular disease [7].

The most important indications for 6 MWT are presented in Table 1.

The absence of a disease or clinical condition listed above does not indicate that the 6MWT is not the optimal and only exercise test that may be applied in the given situation.

Controversies concerning the role of 6MWT in the qualification for lung resection in patients with lung cancer may serve as an example. Despite optimistic initial observations on the prognostic role of 6MWT in these patients [81], guidelines do not indicate $6 \mathrm{MWT}$ as the method of choice in the assessment of exercise capacity and the cardiopulmonary exercise test (CPET) with maximal oxygen uptake $\left(\mathrm{VO}_{2 \max }\right)$ is preferred [82-87]. However, considering the limited availability of CPET in Poland, 6MWT should be performed as a screening test in such patients. In patients with a significant decrease in the 6 minute walk distance (6MWD), CPET should be performed before the disqualification from surgery for lung cancer. Of note, a 6MWD of 500 m corresponds roughly with a $\mathrm{VO}_{2 \max }$ of $15 \mathrm{ml} /$ $\mathrm{kg} / \mathrm{min}[84,88]$, a value which is considered the cut-off point for surgery by most experts in the field. [85, 87, 89].

In some situations, 6MWT may be the only exercise test that the patient is able to perform. This may refer to patients with intellectual disability and mental disorders.

\section{Contraindications}

Table 2 presents the most relevant contraindications for the 6MWT $[4,7,90]$.

Majority of the recommendations for the contraindications do not come from randomized clinical trials and have the form of suggestions with special regard to safety issues. Stable coronary heart disease in not a contraindication for 6MWT, however the patient should receive his or her standard treatment prior to the test and short acting nitrates must readily be available [7]. 
Table 1. Indications and potential applications of the 6MWT

\begin{tabular}{|c|}
\hline Evaluation of functional capacity (single measurement) \\
\hline COPD [8] \\
\hline Pulmonary hypertension [9-11] \\
\hline Heart failure $[12-15]$ \\
\hline Cystic fibrosis $[16,17]$ \\
\hline Interstitial lung diseases $[18,19]$ \\
\hline Peripheral arterial disease [20] \\
\hline Parkinson's disease $[21,22]$ \\
\hline Brain injury (e.g. stroke) [23-25] \\
\hline Elderly disabled patients [26-28] \\
\hline Intellectual disability $[29,30]$ and mental disorders $[31,32]$ \\
\hline Fibromyalgia [33] \\
\hline Recovery after abdominal surgery [34] \\
\hline Qualification for medical interventions and/or follow-up \\
\hline Lung resection \\
\hline Lung transplantation [35-38] \\
\hline Lung volume reduction surgery (LVRS) $[39,40]$ \\
\hline Pulmonary rehabilitation $[41-46]$ \\
\hline Rehabilitation in other conditions [47] \\
\hline COPD [48-51] \\
\hline Pulmonary hypertension $[52,53]$ \\
\hline Heart failure $[14,54,55]$ \\
\hline Predicting survival \\
\hline Heart failure $[56,57]$ \\
\hline COPD $[58-60]$ \\
\hline Primary pulmonary hypertension [61-63] \\
\hline Peripheral arterial disease [64-66] \\
\hline $\begin{array}{l}\text { Chronic liver diseases [67], qualification for liver transplantation } \\
\text { [68] }\end{array}$ \\
\hline $\begin{array}{l}\text { Lung injury in other conditions: } \\
\text { Radiation-induced pulmonary toxicity [69] }\end{array}$ \\
\hline Evaluation of functional capacity in children $[70,71]$ \\
\hline Pulmonary hypertension [72] \\
\hline Evaluation of selected metabolic parameters [73] \\
\hline Diabetes mellitus [74] \\
\hline Cerebral palsy [75], neuromuscular diseases [76-79] \\
\hline Qualification for lung transplantation in cystic fibrosis [80] \\
\hline
\end{tabular}

Literature data indicate that 6MWT is a safe procedure. Despite the large number of tests performed, there are no reports on serious complications, even in patients with heart failure and other diseases [6, 91-93].
Table 2. Contraindications for the 6MWT

\begin{tabular}{|c|c|}
\hline Absolute & Relative \\
\hline $\begin{array}{l}<7-10 \text { days from primary angioplasty due } \\
\text { to STEMI } \\
<24 \text { h from elective coronary angioplasty }\end{array}$ & $\begin{array}{l}\text { Resting heart rate } \\
\quad>120 / \mathrm{min}\end{array}$ \\
\hline Acute myocarditis or pericarditis & $\begin{array}{l}\text { Systolic blood } \\
\text { pressure } \\
>140 \mathrm{~mm} \mathrm{Hg}\end{array}$ \\
\hline Symptomatic arrhythmias & $\begin{array}{l}\text { Diastolic blood } \\
\text { pressure } \\
>90 \mathrm{~mm} \mathrm{Hg}\end{array}$ \\
\hline \multicolumn{2}{|l|}{$\begin{array}{l}\text { Acute deep venous thrombosis, pulmonary } \\
\text { embolism, pulmonary infarction }\end{array}$} \\
\hline \multicolumn{2}{|l|}{ Acute heart failure } \\
\hline $\begin{array}{l}\text { Acute infectious diseases or other con- } \\
\text { ditions which may have relevant impact on } \\
\text { the capability of performing the test (e.g. } \\
\text { severe anemia, acute renal or liver failure, } \\
\text { hypo- or hyperthyroidism etc.) }\end{array}$ & \\
\hline
\end{tabular}

\section{Recommendation}

1. The most important absolute contraindication for $6 \mathrm{MWT}$ is the period of $<7-10$ days from primary coronary angioplasty due to STEMI and $<24 \mathrm{~h}$ from elective angioplasty.

\section{Methodology}

The 6 minute walk test should be performed along a straight and flat corridor with a hard surface and a length of $30 \mathrm{~m}$ [7]. This corridor length was applied in the majority of large studies involving 6MWT [55, 56, 92, 94-98], however other lengths have also been used: 20-25 $\mathrm{m} \mathrm{[13,}$ 14, 57, 99], 45-50 m [100, 101], $90 \mathrm{~m}$ [102] and $125 \mathrm{~m}$ [103]. The walking distance may be shorter in shorter corridors because of more turns to change direction are needed [7]. A study in patients with COPD demonstrated that the 6MWD was approximately $13 \mathrm{~m}$ longer when the test was performed on a $40 \mathrm{~m}$ circular course when compared to a straight $30 \mathrm{~m}$ corridor [104].

Performing the test on a treadmill is not recommended [7]. A comparative analysis of a 12 minute walk test in a $40 \mathrm{~m}$ corridor and on a treadmill showed that the distance walked was longer during the test on the corridor $(791 \pm 224$ $\mathrm{m}$ vs. $742 \pm 224 \mathrm{~m}$ ), however the difference did not reach statistical significance [105]. Swerts et al. also noted a longer distance during the 12 minute walk test performed in a corridor than on a treadmill [106]. Other authors confirmed that 
the distance covered during the test on a corridor is significantly longer than that on a treadmill (374.3 $\pm 77.7 \mathrm{~m}$ vs. $323.1 \pm 118.6)$ [107]. Elazzazi et al., however, did not find any difference between the distance walked in the corridor and the treadmill [108]. In all the three mentioned studies a motorized treadmill was used and the treadmill speed could be modified. Janaudis-Ferreira et al. who compared the performance in tests performed in the corridor and on a non-motorized treadmill found that the distance covered in the corridor was $153 \mathrm{~m}$ longer [109].

The advantage of the 6MWT on a treadmill is that it can be conducted in small spaces.

\section{Required equipment}

6MWT does not have complicated equipment requirements. The following are necessary:

- straight $30 \mathrm{~m}$ long corridor with a hard surface. It is recommended that the corridor should be at least $2-3 \mathrm{~m}$ wide and seldom travelled. The course should be marked every $2 \mathrm{~m}$

- two colored cones which mark the starting point and the end of the lap

- timer

- sphygmomanometer

- pulse oximeter

- a chair/wheelchair

- a worksheet to note the number of laps or a mechanical lap counter (Appendix 1)

- a big-font reprint of the Borg scale (Appendix 2)

- a set of encouraging instructions (Appendix 3)

- referral form (Appendix 4)

- signed informed consent of the patient (Appendix 5).

The evaluation of oxygen saturation during $6 \mathrm{MWT}$ is an important element of the test. A number of studies published recently indicate that there is a relationship between $\mathrm{SpO}_{2}$ decrease during the test and the BODE index [110], the degree of airflow limitation [111, 112], mortality risk [111]. Hypoxemia during exercise is very common in patients with chronic respiratory diseases [48]. Two types of $\mathrm{SpO}_{2}$ variability during the walk test have been documented: a gradual decline with a plateau and return to baseline after the test is completed; a decline at the beginning of the test with subsequent increase during exercise $\left(\mathrm{SpO}_{2}\right.$ at the end of the test is usually lower than baseline and, at the same time, higher than the lowest value recorded during the test) [48, 113, 114]. To obtain a reliable evaluation of oxygen saturation during 6MWT, a continuous $\mathrm{SpO}_{2}$ monitoring during the whole test is recommended.
The better quality of recordings form the finger clip than earlobe sensor $[115,116]$, differences in the measurement accuracy of various devices [117-119] and the potential influence of other factors on the measurements should be considered [120, 121].

For safety reasons, the following should be provided:

- the possibility of immediate contact with the physician responsible for conducting exercise tests or the attending physician of the patient

- access to an oxygen source

- access to a resuscitation kit.

\section{Recommendations}

2. The 6-minute walk test should be performed in a flat and straight corridor with a hard surface and a length of $30 \mathrm{~m}$.

3. Performing the 6MWT on a treadmill is not recommended.

4. The walking course should be marked every $2 \mathrm{~m}$.

5. Continuous oxygen saturation monitoring during 6MWT is indicated.

\section{Methodology of the test}

\section{Patient preparation:}

- the patient should carefully read and sign the informed consent form

- repeated tests (if indicated) should be performed at the same time of the day

- pre-test warm-up is not recommended

- the patient should refrain from intensive exercise within 2 hours before the test

- loose, comfortable clothing which does not affect mobility should be worn

- comfortable non-slip shoes are necessary. The test should not be performed in slippers, high-heel shoes or barefoot

- the test should be performed after a light meal (depending on the time of the day) and administration of the patient's daily medication

- if necessary, usual walking aid (e.g. cane, walker, corset) should be used during the test

\section{Recommendations}

6. The patient should carefully read and sign the informed consent form.

7. Repeated tests should be performed at the same time of the day.

8. Pre-test warm-up is not recommended. 
9. The patient should refrain from intensive exercise within 2 hours before the test.

10. Loose, comfortable clothing which does not affect mobility should be worn.

11. Comfortable non-slip shoes are necessary. The test should not be performed in slippers, high-heel shoes or barefoot.

12. The test should be performed after a light meal (depending on the time of the day) and administration of the patient's daily medication.

13. If necessary, usual walking aid (e.g. cane, walker, corset) should be used during the test.

\section{Technical aspects}

1. The presence of a physician during $6 \mathrm{MWT}$ is not mandatory, however it is indicated in high-risk patients

2. The patient should rest in a sitting position for 5-10 minutes before the test, near the starting point. During this time:

- patient preparation and potential contraindications for the test should be checked

- arterial blood pressure and heart rate should be measured and recorded

- oxygen saturation should be evaluated

- Borg scale should be used to assess dyspnea (all measurements should be noted on the test worksheet)

- the principles of the test should be explained to the patient. It is recommended that every patient is provided with exactly the same information on the test:

The aim of the test is to walk as far as possible for 6 minutes. You will be asked to walk back and forth along this corridor. The exercise you will perform during these six minutes is intensive, therefore you may feel short of breath or tired. You may slow down or even stop and lean against the wall to rest if necessary, but please resume walking as soon as you can [7].

The patient should then get prepared to start the test:

Are you ready to start? Once you start, the counter will be turned on and you will hear it click with every turn, this will be noted on the worksheet. Remember that you are supposed to walk as fast as possible for 6 minutes, so do not jog or run. You may start, when you are ready.

1. The technician should stand close to the starting point and start the counter the moment the patient starts walking. It is not recommended to walk with the patient.
2. The supervising technician should not be distracted and click the lap counter in an expressive manner (for encouragement) or note every turn on the worksheet. Every stop and rest should also be noted. The stopwatch should not be turned off for the time of the rest - this time is included in the duration of the 6MWT.

3. Encouragement of the patient during the test is strongly recommended. An even tone should be used for standard phrases [7]. The motivation should be customized to the patient profile. For example, a 10-year old child and a 75-year old COPD patient with basic education as well as a 40 -year old patient with lung fibrosis require a different set of encouragement phrases. Motivation should be used at one-minute intervals and $15 \mathrm{~s}$ before the end of the test. An example of encouragement sentences is given below:

First minute:

You are doing very well. There are 5 minutes left. Second minute:

Your pace is very good. You have 4 more minutes to go.

\section{Third minute:}

You are doing good. Half of this test is done.

Fourth minute:

Your pace is very good. There are only 2 minutes left .

\section{Fifth minute:}

Keep on walking like this. There is only one minute to go.

$15 \mathrm{~s}$ to the end of the test:

You will be asked to stop in a few moments. When you stop, please wait for me at the point you finished the test.

\section{If the patient stops during the test:}

Please rest, you may lean against the wall, if you need to. Continue walking as soon as you are able.

4. After six minutes, the technician should say loudly: Please stop. If the patient appears exhausted providing him/her with a chair or wheelchair should be considered.

5. Immediately after the end of the test:

- $\mathrm{SpO}_{2}$, heart rate and arterial blood pressure should be measured and recorded on the test worksheet

- dyspnea should be reported (Borg scale). If the patient stopped during the test, the reason why he/she needed to rest should also be noted in the study protocol.

- the distance walked should be calculated by adding the distance from the number of laps 
(1 lap $=60 \mathrm{~m})$ and number of meters in the final lap. The distance should be rounded to the nearest meter.

- the patient should be congratulated on the effort and offered a rest with a glass of water.

\section{Recommendations}

14. The presence of a physician during 6MWT is not mandatory, however it is indicated in high-risk patients.

15. The principles of the 6MWT should be explained to the patient. It is recommended that every patient is provided with exactly the same information on the test.

16. Before the $6 \mathrm{MWT}$ test:

- patient preparation and potential contraindications for the test should be checked

- arterial blood pressure and heart rate should be measured

- oxygen saturation should be evaluated

- Borg scale should be used to assess dyspnea All measurements should be noted on the test worksheet.

17. Every stop and rest should also be noted. The stopwatch should not be turned off for the time of the rest - this time is included in the duration of the 6MWT.

18. To improve effort, the use of standardized encouragement phrases with an even tone during the test is recommended. Motivation should be customized to the patient profile. Encouragement should be used at one-minute intervals and $15 \mathrm{~s}$ before the end of the test.

19. Post-walk evaluation should be done immediately after exercise and include:

$\mathrm{SpO}_{2}$, heart rate and arterial blood pressure

- dyspnea (Borg scale)

- distance walked (calculation with 1 meter accuracy)

- reason for stopping exercise, if the patient stopped during the test

All the above should be recorded in the study protocol.

\section{Factors influencing 6MWD}

Like many other diagnostic test, the result of 6MWT may be influenced by various factors (Table 3).

Methodological factors affecting 6MWD which may be modified include learning effect, the experience of the supervising technician and encouragement intensity during the test.

\section{Table 3. Factors influencing the distance covered during} 6MWT [7]

\author{
6MWD reduction \\ older age [28] \\ shorter height \\ elevated body weight \\ female sex \\ lack of motivation, depression \\ shorter corridor (more turns) [122] \\ inappropriate walking shoes [123] \\ cognitive disorders \\ chronic respiratory diseases [124, 125] \\ chronic vascular diseases [126] \\ chronic musculoskeletal disorders \\ 6MWD increase \\ taller height \\ male sex \\ strong motivation (encouragement during the test) \\ experience in the test performance \\ pre-test administration of medication for disabling disease \\ supplemental oxygen in patients with exercise induced hy- \\ poxemia, $\mathrm{HeO}_{2}$ use [127]
}

\section{Learning effect}

Despite a substantial number of studies which address the reproducibility of 6MWT, it is still not clear if performing a practice test is necessary. According to literature data a practice test may increase $6 M W D$ by $7-17 \%$ [8, 100, 107, 128, 129].

In the opinion of the experts from the ATS, a practice test is not necessary in most clinical settings. Nevertheless, if it is performed, there should be an interval of at least 1 hour between the two tests and the higher 6MWD should be reported [7].

\section{Recommendations}

20. Practice tests are not necessary in patients who achieve normal 6 MWD values in the first test.

21. Practice tests should be considered in:

- patients who have a relatively short 6MWD, which does not correspond with their general condition.

- patients in whom the result of 6MWT may have significant practical implications, e.g. qualification for transplantation, lung resection, modification of medical interventions 
- elderly patients with impairment of motor coordination in whom simple maneuvers (turns) may by problematic

- clinical study participants.

22. There is no evidence for the usefulness of more than 2 practice tests

- practice tests and 6MWT should be performed within a period no longer than 7 days

- when performed the same day, an interval of at least one hour should be kept between subsequent tests

- the longest recorded distance should be considered as the result of the 6MWD.

\section{Technician experience}

The laboratory staff should be trained by the person responsible for exercise tests; training in basic life support is also strongly recommended. Quality control should be performed every 6 months. Quality control is mandatory as it may affect the results of 6MWD. In a study which involved 4 centers and more than 2000 elderly patients, the differences in the methodology of the test (including the application of encouragement) in two centers resulted in a 7\% shorter distance [92].

\section{Recommendations}

23. The laboratory staff should be trained by the person responsible for exercise tests.

24. Technician training in basic life support is also strongly recommended.

25. Quality control should be performed by the person responsible for exercise tests every 6 months.

\section{Encouragement}

The use of encouragement as described in the methodology section is recommended. As previously mentioned, encouragement can improve the walking distance by approximately $30 \mathrm{~m}$. [130]. ATS experts, however, do not recommend encouraging patients to walk as fast as possible, as applied by some authors [100]. Such a motivation may lead to a higher walking speed, earlier termination of exercise and excessive stress for the cardiorespiratory system. [7].

\section{Oxygen supplementation}

When the patient requires oxygen supplementation and repeated tests are necessary, the use of the same source and oxygen flow during the walk test is recommended. The mode of oxygen therapy and oxygen flow should be recorded in the study protocol. Disregarding oxygen supple- mentation during 6MWT leads to misinterpretation of its result.

\section{Interpretation}

6MWT is performed as a single test to assess the functional status of the patient or it may be repeated to evaluate the impact of medical intervention (change in treatment regimen, rehabilitation, oxygen supplementation) on the patient's exercise performance.

The final result of the test should comprise the following information:

- Basic patient data:

- name

- age

- height, weight

- Indication for 6MWT

- Data on methodology of the test

- corridor length

- for tests performed on a treadmill: speed, acceleration mode

- for test performed with oxygen supplementation: oxygen source and oxygen flow

- Walk distance

- absolute value and percent of predicted value; information on the author and source of the reference value should also be provided

- information on the number of stops/time of rest during the test if applicable

- Heart rate

- at rest

- at peak exercise (6 min.)

- Blood pressure

- at rest

- at peak exercise (6 min.)

- Blood oxygen saturation

- at rest

- lowest recorded value

- at peak exercise (6 min.)

- desaturation (the difference between $\mathrm{SpO}_{2}$ at rest and $\mathrm{SpO}_{2}$ at peak exercise)

- Dyspnea according to the Borg scale

- at rest

- at peak exercise (6 min.)

- Comments of the supervising technician

\section{Recommendations}

26. The final result of the test should comprise information on the basic data of the patient, indications for 6MWT, methodology, distance walked and results of the following measurements (at rest and at peak exercise, i.e. after 6 min.): heart rate, blood pressure, blood oxygen saturation and dyspnea. 


\section{Reference values}

No uniform reference values for 6MWD have been established to date. Table 4 presents the most relevant publications on reference values for $6 \mathrm{MWD}$.

The choice of the source of the 6MWD reference equations is the decision of the exercise laboratory team; the reference population should correspond to the study population.

\section{Recommendation}

27. The choice of the source of the 6MWD reference equations is the decision of the exercise laboratory team; the reference population should correspond to the study population

\section{Single measurement interpretation - assessment of functional status}

Both absolute and percent of predicted values of 6MWD should be considered during the interpretation of the result of 6MWT. Despite a number of factors modifying 6MWD, the absolute value of the distance walked provides useful information. In patients with COPD, 6MWD is used to calculate the BODE index, which defines prognosis in this disease. The cut-off values for 6 MWD applied for the stratification of functional impairment severity are $350 \mathrm{~m}, 250 \mathrm{~m}$ and $150 \mathrm{~m}$ [60]. In patients with COPD, absolute 6MWD is an important predictor for mortality, with the lowest risk for patients who achieve a distance longer than $400 \mathrm{~m}$ [58]. Earlier studies on patients qualified for lung resection, reported cut-off values of $300 \mathrm{~m}$ [81] and 450-500 $\mathrm{m}[83,89]$ for predicting postoperative complications.

In patients with Eisenmenger's syndrome, $6 \mathrm{MWD}<350 \mathrm{~m}$ is related with a three-fold increase in mortality risk [133].

Another study showed that a 6MWD $<250 \mathrm{~m}$ in patients with pulmonary hypertension (idio-

Table 4. Reference equations for the $\mathbf{6}$ minute walk distance.

\begin{tabular}{|c|c|c|c|c|c|c|c|}
\hline & Author & No of patients & $\begin{array}{l}\text { Age } \\
\text { (yrs) }\end{array}$ & $\begin{array}{l}\text { Corridor } \\
\text { length }(m)\end{array}$ & Formula - men & Formula - women & $\begin{array}{l}r^{2} \text { of statisti- } \\
\text { cal model }\end{array}$ \\
\hline 1 & $\begin{array}{c}\text { Enright } \\
{[97]}\end{array}$ & $\begin{array}{c}290 \\
(117 \mathrm{M}, 173 \mathrm{~F})\end{array}$ & $40-80$ & 30 & $\begin{array}{c}6 \mathrm{GWD}(\mathrm{m})=(7.57 \times \text { he- } \\
\text { ight })-(5.02 \times \text { age })-(1,76 \\
\times \text { body weight })-309 a\end{array}$ & $\begin{array}{c}\text { 6MWD }(\mathrm{m})=(2.11 \times \text { he- } \\
\text { ight }) \\
-(2.29 \times \text { body weight }) \\
-(5.78 \times \text { age })+667^{\mathrm{b}}\end{array}$ & $\begin{array}{l}\mathrm{F}-0.38 \\
\mathrm{M}-0.42\end{array}$ \\
\hline 2 & $\begin{array}{l}\text { Troosters } \\
{[100]}\end{array}$ & $\begin{array}{c}51 \\
(29 \mathrm{M}, 21 \mathrm{~F})\end{array}$ & $50-85$ & 50 & $\begin{array}{c}6 \mathrm{MWD}(\mathrm{m})=218+(5.14 \times \\
\text { height }-5.32 \\
\times \text { age })-(1.80 \times \text { body we- } \\
\text { ight }+51.31) \mathrm{c}\end{array}$ & $\begin{array}{c}6 \mathrm{MWD}(\mathrm{m})=218+(5.14 \times \\
\text { height }-5.32 \times \text { age })-(1.80 \\
\quad \times \text { body weight })^{\mathrm{c}}\end{array}$ & 0.66 \\
\hline 3 & $\begin{array}{l}\text { Camarri } \\
\text { [101] }\end{array}$ & $\begin{array}{c}70 \\
(33 \mathrm{M}, 37 \mathrm{~F})\end{array}$ & $55-75$ & 45 & $\begin{array}{c}\text { 6MWD }(\mathrm{m})=216.9 \\
+(4.12 \times \text { height })-(1.75 \times \\
\text { age })-(1.15 \times \text { body weight })\end{array}$ & $\begin{array}{c}6 \mathrm{MWD}(\mathrm{m})=216.9+(4.12 \\
\times \text { height })-(1.75 \times \text { age })- \\
(1.15 \times \text { body weight })-34.04\end{array}$ & 0.36 \\
\hline 4 & $\begin{array}{c}\text { Gibbons } \\
\text { [131] }\end{array}$ & $\begin{array}{c}79 \\
(41 \mathrm{M}, 38 \mathrm{~F})\end{array}$ & $20-80$ & 20 & $\begin{array}{c}\text { 6MWD }(\mathrm{m})=868.8 \\
-(\text { age } \times 2.99)\end{array}$ & $\begin{array}{c}6 \mathrm{MWD}(\mathrm{m})=868.8-\text { (age } \\
\times 2.99)-7.47\end{array}$ & 0.41 \\
\hline 5 & $\begin{array}{c}\text { Enright } \\
\text { [92] }\end{array}$ & $\begin{array}{c}2117 \\
\left(853 \mathrm{M}_{,} 1264\right. \\
\mathrm{K})\end{array}$ & $\geq 68$ & 30 & $\begin{array}{l}6 \mathrm{MWD}(\mathrm{m})=493+(2.2 \\
\times \text { height })-(0.93 \times \text { body } \\
\text { weight })-(5.3 \times \text { age })+17 \mathrm{~d}\end{array}$ & $\begin{array}{c}6 \mathrm{MWD}(\mathrm{m})=493+(2.2 \\
\times \text { height })-(0.93 \times \text { body } \\
\text { weight })-(5.3 \times \text { age })^{\mathrm{d}}\end{array}$ & 0.2 \\
\hline 6 & $\begin{array}{l}\text { Chetta } \\
\text { [98] }\end{array}$ & $\begin{array}{c}102 \\
(48 \mathrm{M}, 54 \mathrm{~F})\end{array}$ & $20-50$ & 30 & $\begin{array}{c}6 \mathrm{MWD}(\mathrm{m})=518.53+ \\
(1.25 \times \text { height })-(2.816 \times \\
\text { age })\end{array}$ & $\begin{array}{c}6 \mathrm{MWD}(\mathrm{m})=518.53+ \\
(1.25 \times \text { height })-(2.816 \times \\
\text { age })-39.07\end{array}$ & 0.42 \\
\hline 7 & $\begin{array}{l}\text { Casanova } \\
\text { [93] }\end{array}$ & $\begin{array}{c}444 \\
(238 \mathrm{M}, 206 \mathrm{~F})\end{array}$ & $40-80$ & 30 & $\begin{array}{c}6 \mathrm{MWD}(\mathrm{m})=361-(\text { age } \times 4) \\
+(\text { height } \times 2)+\left(\mathrm{HR}_{\text {max\% }} \mathrm{HR}-\right. \\
\max \times 3) \\
-(\text { body weight } \times 1.5)\end{array}$ & $\begin{array}{c}6 \mathrm{MWD}(\mathrm{m})=361-(\text { age } \times 4) \\
+(\text { height } \times 2)+\left(\mathrm{HR}_{\max \%} \mathrm{HR}-\right. \\
\operatorname{MAx} \times 3)-(\text { body weight } \times 1.5) \\
-30\end{array}$ & 0.38 \\
\hline 8 & $\begin{array}{l}\text { Geiger } \\
\text { [99] }\end{array}$ & $\begin{array}{c}456 \\
(208 \mathrm{M}, 248 \mathrm{~F})\end{array}$ & $3-18$ & 20 & $\begin{array}{c}\text { 6MWD }(\mathrm{m})=196.72 \\
+(39.81 \times \text { age })- \\
\left(1.36 \times \text { age }^{\wedge} 2\right)+ \\
(13.28 \times \text { height })\end{array}$ & $\begin{array}{c}6 \mathrm{MWD}(\mathrm{m})=188.61 \\
+(51.50 \times \text { age })- \\
\left(1.86 \times \mathrm{age}^{\wedge} 2\right)+ \\
(86.10 \times \text { height })\end{array}$ & $\begin{array}{l}M-0.49 \\
F-0.50\end{array}$ \\
\hline 9 & $\begin{array}{c}\text { Prusak } \\
{[132]}\end{array}$ & $\begin{array}{l}545(261 \mathrm{M}, \\
284 \mathrm{~F})\end{array}$ & $7-18$ & $\begin{array}{l}\text { the test was } \\
\text { performed in } \\
\text { a } 20 \times 30 \mathrm{~m} \\
\text { sports hall }\end{array}$ & $\begin{array}{c}6 \mathrm{MWD}(\mathrm{m})=374.9 \\
+(2.22 \times \text { age })+(3.53 \times \text { he }- \\
\text { ight }) \\
-(1.71 \times \text { body weight })\end{array}$ & $\begin{array}{c}6 \mathrm{MWD}(\mathrm{m})=419.8 \\
+(14.99 \times \text { age })+(2.56 \times \text { he- } \\
\text { ight })-(3.03 \times \text { body weight })\end{array}$ & $\begin{array}{l}M-0.54 \\
F-0.48\end{array}$ \\
\hline
\end{tabular}

HRmax\%HRMAX - heart rate at peak exercise at the end of 6MWT (HRmax) expressed as percent of predicted maximal heart rate (HRMAX) calculated as follows HRMAX $=220$-age

${ }^{a}$ to calculate lower limit of normal (LLN) subtract 153 from obtained value

b to calculate lower limit of normal (LLN) subtract 139 from obtained value

${ }^{c}$ residual standard deviation $(\mathrm{RSD})=56 \mathrm{~m}$

${ }^{d}$ to calculate lower limit of normal (LLN) subtract 100 from obtained value 
pathic and related with interstitial lung disease) is associated with a $50 \%$ mortality risk within 2 years [62]. In patients with idiopathic pulmonary hypertension, the 6MWD cut-off value which predicts survival was established at $332 \mathrm{~m}$ [61]. According to experts from the American College of Cardiology, an increase in 6MWD to $\geq 380-440 \mathrm{~m}$ should be one of the goals of treatment in idiopathic pulmonary hypertension [11].

In patients with heart failure, $6 \mathrm{MWD}<300 \mathrm{~m}$ is associated with a significantly higher mortality compared to patients with 6MWD > $300 \mathrm{~m} \mathrm{(10 \%}$ vs. 3\%) [56]. Significant differences in mortality risk were also observed in patients with 6MWD $<300 \mathrm{~m}, 300-450 \mathrm{~m}$ and $>450 \mathrm{~m}$ [134].

A decrease in 6MWD is also a significant prognostic factor in idiopathic pulmonary fibrosis (IPF). Lederer et al. showed that in patients with IPF, a $6 \mathrm{MWD}<207 \mathrm{~m}$ (considering the influence a number of other factors) is related with a four-fold higher mortality [63]. Another study showed that the cut-off value for 6MWD which defines functional impairment and has a significant impact on mortality risk in patients with IPF is $350 \mathrm{~m}$ [135].

Despite of a number of reference equations proposed by various authors, no algorithm for the interpretation 6MWD expressed as percent of predicted value has been established to date. Troosters et al. propose that a 6MWD below $82 \%$ of predicted value should be treated as abnormal [100]. The lower limit of normal for 6MWD may be calculated from equation 1[97] or 5 [92] presented in Table 4.

Equation 2 [100] may be applied for the calculation of residual standard deviation with the use of the following formula.

$\mathrm{SR}=($ actual value- predicted value $) / \mathrm{RSD}$

\section{Changes in blood oxygen saturation}

Desaturation during 6MWT may indicate gas exchange impairment during exercise [136, 137]. A decrease of $\mathrm{SpO}_{2}$ by $\geq 4 \%$ or $\mathrm{SpO}_{2}<88 \%$ or $90 \%$ during exercise is considered clinically significant $[4,138,139]$.

\section{Interpretation - minimal important difference}

Although numerous studies addressed the impact of medical interventions on 6MWT, it is still not clear if the changes in 6MWD should be expressed as an absolute value, relative difference or as the difference in percent of predicted value. It seems that presenting the difference as an absolute value is optimal, as it enables com- parative analysis with other studies which may use different reference equations.

The evaluation of the potential effect of medical interventions is strictly related to the so called minimal important difference - MID or minimally clinically important difference - MICD which is used to describe the minimal significant change in 6MWD which is associated with improvement/ deterioration of functional performance reported by the patients.

Many authors apply the MID cut-off value of $54 \mathrm{~m}$ (95\% CI 37-71 m) proposed by Riedelmeier et al. who analyzed a group of 112 patients with COPD [140]. In other studies, the MID ranged between 26 and $80 \mathrm{~m}$ [141-143]. In the ECLIPSE study, a $>30 \mathrm{~m}$ decrease in 6MWD within 12 months was associated with a higher mortality risk (hazard ratio 1.93) [96].

In elderly patients with heart failure, the reported MID was 24-48 $\mathrm{m}$, depending on the self-reported change in functional performance (slight improvement - significant deterioration)[144].

In patients with pulmonary hypertension, an MID of $33 \mathrm{~m}$ was established with a range of 25-39 $\mathrm{m}$ depending on the reference equation applied [145]. The MID for patients with idiopathic pulmonary hypertension is $24-45$ $\mathrm{m}$, and a decrease of $>50 \mathrm{~m}$ in 6MWD within 24 weeks is a negative prognostic factor and is related with an at least four-fold higher mortality risk [146].

\section{Impact of interventions on 6MWD}

One of the first reports on 6 MWT showed that supplemental oxygen $(2 \mathrm{~L} / \mathrm{min}$ and $4 \mathrm{~L} / \mathrm{min})$ improved 6MWD by $51 \mathrm{~m}$ and $75 \mathrm{~m}$, respectively, however when portable oxygen was applied, the improvement was irrelevant [147]. Leach et al. demonstrated that the use of portable liquid oxygen with $\mathrm{FiO}_{2} 0.28,0.4$ and 0.53 resulted in an increase in $6 \mathrm{MWD}$ by $19.2 \%, 34.5 \%$ and $36.3 \%$ when compared to the test performed with the use of an oxygen cylinder of a similar weight as the device with liquid oxygen. Moreover, the degree of desaturation as well as dyspnea were lower [129].

Pulmonary rehabilitation is reported to increase $6 \mathrm{MWD}$ by $40-48 \mathrm{~m}[124,148]$.

Lung volume reduction surgery increases the 6MWD by approximately $55 \mathrm{~m}$ [149].

Rehabilitation also improves exercise performance in patients with cardiovascular diseases; a 6MWD increase of approximately $60 \mathrm{~m}$ may be observed [150]. 


\section{Recommendations}

28. A significant decrease in $6 \mathrm{MWD}$ is defined as a decline $<82 \%$ of predicted value or below the lower limit of normal.

29. A decrease of $\mathrm{SpO}_{2} \geq 4 \%$ (as compared to $\mathrm{SpO}_{2}$ at rest) or below $88 \%$ (or $90 \%$ ) is considered clinically significant.

30. Disease specific minimal important difference (MID) should be considered in the analysis of the impact of medical interventions on $6 \mathrm{MWD}$.

\section{References}

1. Singh S. Walking for the assessment of patients with chronic obstructive pulmonary disease. Clinical Exercise Testing. European Respiratory Society Journals Ltd. 2007; $148-164$.

2. Woerlee GM. NYHA classification of cardiac functional disability. Common Perioperative Problems And The Anaesthetist. Developments in Critical Care Medicine and Anesthesiology 1988; 18: 31-31.

3. Stenton C. The MRC breathlessness scale. Occupational Medicine 2008; 58: 226-227.

4. American Thoracic Society, American College of Chest Physicians ATS/ACCP Statement on cardiopulmonary exercise testing. Am J Respir Crit Care Med 2003; 167: 211-277.

5. Zeballos RJ, Weisman IM. Modalities of clinical exercise testing. Clinical Exercise Testing. Weisman IM, Zeballos RJ (eds). Prog Respir Res. Basel, Karger, 2002; 32: 30-42. DOI:10.1159/000062229

6. Solway S, Brooks D, Lacasse Y et al. A qualitative systematic overview of the measurement properties of functional walk tests used in the cardiorespiratory domain. Chest 2001; 119 : $256-270$.

7. ATS Committee on Proficiency Standards for Clinical Pulmonary Function Laboratories. ATS Statement: Guidelines for the six-minute walk test. Am J Respir Crit Care Med 2002; 166: $111-117$.

8. Sciurba F, Criner GJ, Lee SM et al. Six-minute walk distance in Chronic Obstructive Pulmonary Disease. Am J Respir Crit Care Med 2003; 167: 1522-1527.

9. Galie N, Hoeper MM, Humbert M et al. Guidelines for the diagnosis and treatment of pulmonary hypertension. Eur Respir J 2009; 34: 1219-1263. doi: 10.1183/09031936.00139009.

10. Mainguy V, Provencher S, Maltais F et al. Assessment of daily life physical activities in pulmonary arterial hypertension. PLoS One 2011; 6: e27993. doi: 10.1371/journal.pone.0027993

11. Mclaughlin VV, Gaine SP, Howard LS et al. Treatment goals of pulmonary hypertension. Am J Coll Cardiol 2013; 62: D73D81. doi: 10.1016/j.jacc.2013.10.034.

12. Guyatt GH, Sullivan MJ, Thompson PJ et al. The 6-minute walk: a new measure of exercise capacity in patients with chronic heart failure. Can Med Assoc J 1985; 132: 919-923.

13. Lipkin DP, Scriven AJ, Crake T, Poole-Wilson PA. Six minute walking test for assessing exercise capacity in chronic heart failure. Br Med J (Clin Research Ed) 1986; 292: 653-655.

14. Demers C, Mckelvie RS, Negassa A Yusuf S; RESOLVD Pilot Study Investigators. Reliability, validity, and responsiveness of the Six-minute walk test in patients with heart failure. Am Heart J 2001; 142: 698-703.

15. Ingle L, Shelton R.J, Rigby Nabb S, Clark AL, Cleland JG. The reproducibility and sensitivity of the 6-min walk test in elderly patients with chronic heart failure. Eur Heart J 2005; 26: $1742-1751$.

16. Ziegler B, Rovedder PME, Oliveira CL de Abreu e Silva F, de Tarso Roth Dalcin P. Repeatability of the 6-minute walk test in adolescents and adults with cystic fibrosis. Respir Care 2010; 55: $1020-1025$

17. Chetta A, Pisi G, Zanini A et al. Six-minute walking test in cystic fibrosis adults with mild to moderate lung disease: comparison to healthy subjects. Respir Med 2001; 95 986-991.

18. Eaton T, Young P, Milne D Wells AU. Six-minute walk, maximal exercise tests: Reproducibility in fibrotic interstitial pneumonia. Am J Respir Crit Care Med 2005; 171: 1150-1157.

19. Baughman RP, Sparkman BK, Lower EE. Six-minute walk test and health status assessment in sarcoidosis. Chest 2007; 132: 207-213.

20. Andreozzi GM, Arosio E, Martini R Verlato F, Visonà A. Consensus Document on Intermittent Claudication from the Central European Vascular Forum $1^{\text {st }}$ edition - Abano Terme (Italy) - May $20052^{\text {nd }}$ revision - Portroz (Slovenia) September 2007. Int Angiol 2008; 27: 93-113.

21. Steffen T, Seney M. Test-retest reliability and minimal detectable change on balance and ambulation tests, the 36-Item Short-Form Health Survey, and the unified Parkinson disease rating scale in people with parkinsonism. Phys Ther 2008; 88: 733-746.

22. Garber CE, Friedman JH. Effects of fatigue on physical activity and function in patients with Parkinson's disease. Neurology 2003; 60: 1119-1124.

23. Moriello C, Finch L, Mayo NE. Relationship between muscle strength and functional walking capacity among people with stroke. J Rehabil Res Dev 2011; 48: 267-275.

24. Pradon D, Roche N, Enette L, Zory R. Relationship between lower limb muscle strength and 6-minute walk test performance in stroke patients. J Rehabil Med 2013; 45: 105-108. doi: 10.2340/16501977-1059.

25. Mossberg KA, Fortini E. Responsiveness and validity of the Six-minute walk test in individuals with traumatic brain injury. Phys Ther 2012; 92: 726-733. doi: 10.2522/ptj.20110157.

26. Simonsick EM, Montgomery PS, Newman AB, Bauer DC, Harris T. Measuring fitness in healthy older adults: The health $\mathrm{ABC}$ long distance corridor walk. J Am Geriatr Soc 2001; 49: 1544-1548.

27. Bean J.F, Kiely D.K, Leveille S.G et al. The 6 -minute walk test in mobility-limited elders: What is being measured? J Gerontol A Biol Sci Med Sci 2002; 57: M751-M756.

28. Steffen TM, Hacker TA, Mollinger L. Age- and gender-related test performance in community-dwelling elderly people: Six -minute Walk Test, Berg Balance Scale, Timed Up \& Go Test, and gait speeds. Phys Ther 2002; 82: 128-137.

29. Waninge A, Evenhuis I.J, Van Wijck R, van der Schans CP. Feasibility and reliability of two different walking tests in people with severe intellectual and sensory disabilities. JARID 2011, 24: 518-527. doi: 10.1111/j.1468-3148.2011.00632.x

30. Nasuti G, Stuart-Hill L, Temple V.A. The Six-minute walk test for adults with intellectual disability: A study of validity and reliability. J Intellect Dev Disabil. 2013; 38: 31-38. doi: 10.3109/13668250.2012.748885.

31. Vancampfort D, Probst M, Sweers K, Maurissen K, Knapen J, De Hert M.Relationships between obesity, functional exercise capacity, physical activity participation and physical self-perception in people with schizophrenia. Acta Psychiatr Scand 2011; $123: 423-430$.

32. Vancampfort D, Probst M, Sweers K, Maurissen K, Knapen J, De Hert M. Reliability, minimal detectable changes, practice effects and correlates of the 6-min walk test in patients with schizophrenia. Psychiatry Res 2011; 187: 62-67.

33. King S, Wessel J, Bhambhani Y, Maikala R, Sholter D, Maksymowych W. Validity and reliability of the 6 minute walk in persons with fibromyalgia. The Journal of rheumatology 1999; 26: $2233-2237$

34. Moriello C, Mayo N.E, Feldman L, Carli F. Validating the Six-minute walk test as a measure of recovery after elective colon resection surgery. Arch Phys Med Rehabil 2008; 89: 1083-1089. doi: 10.1016/j.apmr.2007.11.031.

35. Kadikar A, Maurer J, Kesten S. The Six-minute walk test: a guide to assessment for lung transplantation. J Heart Lung Transplant 1997; 16: 313-319.

36. Seoane L, Alex S, Pirtle C et al. Utility of the 6-minute walk test following lung transplantation. Ochsner J 2010; 10: 227-230.

37. Egan T.M, Murray S, Bustami R.T et al. Development of the new lung allocation system in the United States. Am J Transplant 2006; 6: 1212-1227.

38. Jastrzębski D, Kozielski J, Nowak J et al. Ciśnienie parcjalne tlenu po suplementacji przez cewnik donosowy oraz test 
6-minutowego chodu jako czynniki prognostyczne u chorych z idiopatycznym włóknieniem płuc kwalifikowanych do przeszczepu płuc. Kardiochirurgia i Torakochirurgia Polska 2005; 2: 63-67.

39. Criner G.J, Cordova F.C, Furukawa $\mathrm{S}$ et al. Prospective randomized trial comparing bilateral lung volume reduction surgery to pulmonary rehabilitation in severe chronic obstructive pulmonary disease. Am J Respir Crit Care Med 1999; 160: 2018-2027.

40. Sciurba F.C, Rogers R.M, Keenan R.J et al. Improvement in pulmonary function and elastic recoil after lung-reduction surgery for diffuse emphysema. N Engl J Med 1996; 334: 1095-1099.

41. Sinclair DJ, Ingram CG. Controlled trial of supervised exercise training in chronic bronchitis. Br Med J 1980; 280: 519-521.

42. Roomi J, Johnson M.M, Waters K Yohannes A, Helm A, Connolly MJ. Respiratory rehabilitation, exercise capacity and quality of life in chronic airways disease in old age. Age Ageing 1996; 25: $12-16$.

43. Reis LF, Guimaraes FS, Fernandes SJ et al. A long-term pulmonary rehabilitation program progressively improves exercise tolerance, quality of life and cardiovascular risk factors in patients with COPD. Eur J Phys Rehabil Med 2013; 49: 491-497.

44. Huppmann P, Sczepanski B, Boensch M et al. Effects of inpatient pulmonary rehabilitation in patients with interstitial lung disease. Eur Respir J 2013; 42: 444-453. doi: 10.1183/09031936.00081512.

45. Beauchamp MK, Francella S, Romano JM Goldstein RS, Brooks D. A novel approach to long-term respiratory care: results of a community-based post-rehabilitation maintenance program in COPD. Respir Med 2013; 107: 1210-1216. doi: 10.1016/j. rmed.2013.04.014

46. Jastrzebski D, Ochman M, Ziora D et al. Pulmonary rehabilitation in patients referred for lung transplantation. Adv Exp Med Biol 2013; 755: 19-25.

47. Foroncewicz B, Mucha K, Szparaga B et al. Rehabilitation and 6-minute walk test after liver transplantation. Transplant Proc 2011; 43: 3021-3024. doi: 10.1016/j.transproceed.2011.08.007.

48. Spence D.P, Hay J.G, Carter J Pearson MG, Calverley PM. Oxygen desaturation and breathlessness during corridor walking in chronic obstructive pulmonary disease: effect of oxitropium bromide. Thorax 1993; 48: 1145-1150.

49. Cote C, Pearle J.L, Sharafkhaneh A Spangenthal S. Faster onset of action of formoterol versus salmeterol in patients with chronic obstructive pulmonary disease: A multicenter, randomized study. Pulm Pharmacol Ther 2009; 22: 44-49. doi: 10.1016/j. pupt.2008.11.010.

50. Criner GJ, Cordova F, Sternberg AL Martinez FJ. The National Emphysema Treatment Trial (NETT) Part I: Lessons learned about emphysema. Am J Respir Crit Care Med 2011; 184: 763-770. doi: 10.1164/rccm.201103-0454CI.

51. Mentz RJ, Schulte PJ, Fleg JL et al. Clinical characteristics, response to exercise training, and outcomes in patients with heart failure and chronic obstructive pulmonary disease: Findings from Heart Failure and A Controlled Trial Investigating Outcomes of Exercise TraiNing (HF-ACTION). Am Heart J 2013; 165: 193-199. doi: 10.1016/j.ahj.2012.10.029.

52. Van Der Plas MN, Surie S, Reesink HJ van Steenwijk RP, Kloek JJ, Bresser P. Longitudinal follow-up of Six-minute walk distance after pulmonary endarterectomy. Ann Thorac Surg 2011; 91: 1094-1099. doi: 10.1016/j.athoracsur.2010.11.061.

53. Martínez-Quintana E, Miranda-Calderín G, Ugarte-Lopetegui A, Rodríguez-González F. Rehabilitation program in adult congenital heart disease patients with pulmonary hypertension. Congenit Heart Dis 2010; 5: 44-50. doi: 10.1111/j. 1747-0803.2009.00370.x.

54. Stevenson LW, Sietsema K, Tillisch JH et al. Exercise capacity for survivors of cardiac transplantation or sustained medical therapy for stable heart failure. Circulation 1990; 81: 78-85.

55. Bittner V. Role of the 6-minute walk test in cardiac rehabilitation. In: Kraus W, Keteyian S (ed.) Cardiac rehabilitation. New York 2007; 131-139.

56. Bittner V, Weiner D.H, Yusuf S et al. Prediction of mortality and morbidity with a 6-minute walk test in patients with left ventricular dysfunction. SOLVD Investigators. JAMA 1993; 270: $1702-1707$
57. Forman D.E, Fleg J.L, Kitzman D.W et al. 6-min walk test provides prognostic utility comparable to cardiopulmonary exercise testing in ambulatory outpatients with systolic heart failure. J Am Coll Cardiol 2012; 60: 2653-2661. doi: 10.1016/j. jacc.2012.08.1010

58. Pinto-Plata V.M, Cote C, Cabral H, Taylor J, Celli BR. The 6-min walk distance: change over time and value as a predictor of survival in severe COPD. Eur Respir J 2004; 23: 28-33.

59. Golpe R, Pérez-De-Llano LA, Méndez-Marote L, Veres-Racamonde A. Prognostic value of walk distance, work, oxygen saturation, and dyspnea during 6-minute walk test in COPD patients. Respir Care 2013; 58: 1329-1334. doi: 10.4187/respcare.02290.

60. Celli BR, Cote CG, Marin JM et al. The body-mass index, airflow obstruction, dyspnea, and exercise capacity index in chronic obstructive pulmonary disease. N Engl J Med 2004; 350: $1005-1012$.

61. Miyamoto S, Nagaya N, Satoh T et al. Clinical correlates and prognostic significance of Six-minute walk test in patients with primary pulmonary hypertension. Comparison with cardiopulmonary exercise testing. Am J Respir Crit Care Med 2000; 161: 487-492

62. Fritz JS, Blair C, Oudiz RJ et al. Baseline and follow-up 6-min walk distance and brain natriuretic peptide predict 2-year mortality in pulmonary arterial hypertension. Chest 2013; 143: $315-323$.

63. Lederer DJ, Arcasoy SM, Wilt JS, D’Ovidio F, Sonett JR, Kawut SM. Six-minute-walk distance predicts waiting list survival in idiopathic pulmonary fibrosis. Am J Respir Crit Care Med 2006; 174: $659-664$

64. Mcdermott M.M, Liu K.A, Ferrucci L et al. Decline in functional performance predicts later increased mobility loss and mortality in peripheral arterial disease. J Am Coll Cardiol 2011; 57: 962-970. doi: 10.1016/j.jacc.2010.09.053.

65. Garg PK, Liu K, Tian L et al. Physical activity during daily life and functional decline in peripheral arterial disease. Circulation 2009; 119: 251-260. doi: 10.1161/CIRCULATIONAHA.108.791491.

66. Mcdermott M.M, Tian L, Liu K et al. Prognostic value of functional performance for mortality in patients with peripheral artery disease. J Am Coll Cardiol 2008; 51: 1482-1489. doi: 10.1016/j.jacc.2007.12.034.

67. Alameri H.F, Sanai F.M, Al Dukhayil M et al. Six minute walk test to assess functional capacity in chronic liver disease patients. World J Gastroenterol 2007; 13: 3996-4001.

68. Carey EJ, Steidley DE, Aqel BA et al. Six-minute walk distance predicts mortality in liver transplant candidates. Liver Transpl 2010; 16: 1373-1378. doi: 10.1002/lt.22167.

69. Miller KL, Kocak Z, Kahn D et al. Preliminary report of the 6-minute walk test as a predictor of radiation-induced pulmonary toxicity. Int J Radiat Oncol Biol Phys 2005; 62: 1009-1013.

70. Bartels B, De Groot JF, Terwee CB. The Six-minute walk test in chronic pediatric conditions: a systematic review of measurement properties. Phys Ther 2013; 93: 529-541. doi: 10.2522/ ptj.20120210.

71. Hassan J, Van Der Net J, Helders PJM, Prakken BJ, Takken T. Six-minute walk test in children with chronic conditions. Br J Sports Med 2010; 44: 270-274. doi: 10.1136/ bjsm.2008.048512.

72. Lammers AE, Diller GP, Odendaal D, Tailor S, Derrick G, Haworth SG. Comparison of 6-min walk test distance and cardiopulmonary exercise test performance in children with pulmonary hypertension. Arch Dis Child 2011; 96: 141-147. doi: 10.1136/adc.2009.169904

73. Makni E, Moalla W, Trabelsi Y et al. Six-minute walking test predicts maximal fat oxidation in obese children. Int J Obes (Lond) 2012; 36: 908-913. doi: 10.1038/ijo.2011.257.

74. Jegdic V, Roncevic Z, Skrabic V. Physical fitness in children with type 1 diabetes measured with Six-minute walk test. Int J Endocrinol 2013; 2013: 190454. doi: 10.1155/2013/190454.

75. Thompson P, Beath T, Bell J et al. Test-retest reliability of the 10-metre fast walk test and 6-minute walk test in ambulatory school-aged children with cerebral palsy. Dev Med Child Neurol 2008; 50: 370-376. doi: 10.1111/j.1469-8749.2008.02048.x. 
76. Mcdonald C.M, Henricson E.K, Han J.J et al. The 6-minute walk test as a new outcome measure in Duchenne muscular dystrophy. Muscle Nerve 2010; 41: 500-510. doi: 10.1002/ mus.21544.

77. Mazzone E, Bianco F, Main M et al. Six minute walk test in type III spinal muscular atrophy: A 12 month longitudinal study. Neuromuscul Disord 2013; 23: 624-628. doi: 10.1016/j. nmd.2013.06.001.

78. Lerario A, Bonfiglio S, Sormani M et al. Quantitative muscle strength assessment in duchenne muscular dystrophy: longitudinal study and correlation with functional measures. BMC Neurol 2012; 12: 91. doi: 10.1186/1471-2377-12-91.

79. Mazzone E.S, Pane M, Sormani M.P et al. 24 month longitudinal data in ambulant boys with Duchenne muscular dystrophy. PLoS One 2013; 8: e52512. doi: 10.1371/journal.pone.0052512.

80. Radtke T, Faro A, Wong J, Boehler A, Benden C. Exercise testing in pediatric lung transplant candidates with cystic fibrosis. Pediatr Transplant. 2011; 15: 294-299. doi: 10.1111/j. 1399-3046.2010.01471.x.

81. Holden DA, Rice TW, Stelmach K, Meeker DP. Exercise testing, 6-min walk, and stair climb in the evaluation of patients at high risk for pulmonary resection. Chest 1992; 102: 1774-1779.

82. Mazzone P. Preoperative evaluation of the lung resection candidate. Clevel Clin J Med 2012; 79 (e-Suppl 1): e-S17-e-S22. doi:10.3949/ccjm.79.s2.04

83. Brunelli A, Pompili C, Salati M. Low-technology exercise test in the preoperative evaluation of lung resection candidates. Monaldi Arch Chest Dis 2010; 73: 72-78.

84. Brunelli A, Charloux A, Bolliger CT et al. ERS/ESTS clinical guidelines on fitness for radical therapy in lung cancer patients (surgery and chemo-radiotherapy). Eur Respir J 2009; 34: 17-41. doi: 10.1183/09031936.00184308.

85. Colice GL, Shafazand S, Griffin JP, Keenan R, Bolliger CT; American College of Chest Physicians. Physiologic evaluation of the patient with lung cancer being considered for resectional surgery: ACCP evidenced-based clinical practice guidelines ( $2^{\text {nd }}$ edition). Chest 2007; 132 (Suppl): 161s-177s.

86. Donington J, Ferguson M, Mazzone P et al. American College of Chest Physicians and Society of Thoracic Surgeons Consensus statement for evaluation and management for high-risk patients with stage I non-small cell lung cancer. Chest 2012; 142: 1620-1635. doi: 10.1378/chest.12-0790.

87. David EA, Marshall MB. Physiologic evaluation of lung resection candidates. Thorac Surg Clin 2012; 22: 47-54, vi. doi: 10.1016/j.thorsurg.2011.08.013.

88. Turner SE, Eastwood PR, Cecins NM, Hillman DR, Jenkins SC. Physiologic responses to incremental and self-paced exercise in COPD: a comparison of three tests. Chest 2004; 126: 766-773.

89. Van Tilburg PMB, Stam H, Hoogsteden HC, van Klaveren RJ. Pre-operative pulmonary evaluation of lung cancer patients: a review of the literature. Eur Respir J 2009; 33: 1206-1215. doi: 10.1183/09031936.00020508.

90. Task Force on Myocardial Revascularization of the European Society of Cardiology (ESC) and the European Association for Cardio-Thoracic Surgery (EACTS) et al. Guidelines on myocardial revascularization. Eur Heart J 2010; 31: 2501-2555. doi: 10.1093/eurheartj/ehq277.

91. Enright PL. The Six-minute walk test. Respir Care 2003; 48: 783-785.

92. Enright PL, Mcburnie MA, Bittner V et al. The 6-min walk test: a quick measure of functional status in elderly adults. Chest 2003; 123 : $387-398$.

93. Casanova C, Celli B.R, Barria P et al. The 6-min walk distance in healthy subjects: reference standards from seven countries. Eur Respir J 2011; 37: 150-156. doi: 10.1183/09031936.00194909.

94. Ketchell RI, Roughton M, Agent P Gyi K, Hodson ME. Predicting survival in end-stage cystic fibrosis. Respir Med 2009; 103: 1441-1447. doi: 10.1016/j.rmed.2009.04.025.

95. Opasich C, De Feo S, Pinna GD et al. Distance walked in the 6-minute test soon after cardiac surgery - toward an efficient use in the individual patient. Chest 2004; 126: 1796-1801.

96. Polkey MI, Spruit MA, Edwards LD et al. Six-minute-walk test in chronic obstructive pulmonary disease: minimal clinically important difference for death or hospitalization. Am
J Respir Crit Care Med 2013; 187: 382-386. doi: 10.1164/ rccm.201209-15960C.

97. Enright PL, Sherrill DL. Reference equations for the Six-minute walk in healthy adults. Am J Respir Crit Care Med 1998; 158: $1384-1387$

98. Chetta A, Zanini A, Pisi G et al. Reference values for the 6min walk test in healthy subjects $20-50$ years old. Respir Med 2006; 100: 1573-1578.

99. Geiger R, Strasak A, Treml B et al. Six-minute walk test in children and adolescents. J Pediatr 2007; 150: 395-399.

100. Troosters T, Gosselink R, Decramer M. Six minute walking distance in healthy elderly subjects. Eur Respir J 1999; 14: 270-274.

101. Camarri B, Eastwood PR, Cecins NM, Thompson PJ, Jenkins S. Six minute walk distance in healthy subjects aged 55-75 years. Respir Med 2006; 100: 658-665.

102. Troosters T, Vilaro J, Rabinovich R et al. Physiological responses to the 6-min walk test in patients with chronic obstructive pulmonary disease. Eur Respir J 2002; 20: 564-569.

103. Hernandes NA, Wouters EF, Meijer K, Annegarn J, Pitta F, Spruit MA. Reproducibility of 6-minute walking test in patients with COPD. Eur Respir J 2011; 38: 261-267. doi: 10.1183/09031936.00142010.

104. Bansal V, Hill K, Dolmage TE, Brooks D, Woon LJ, Goldstein RS. Modifying track layout from straight to circular has a modest effect on the 6-min walk distance. Chest 2008; 133 : 1155-1160. doi: 10.1378/chest.07-2823.

105. Beaumont A, Cockcroft A, Guz A. A self paced treadmill walking test for breathless patients. Thorax 1985; 40: 459-464.

106. Swerts PM, Mostert R, Wouters EF. Comparison of corridor and treadmill walking in patients with severe chronic obstructive pulmonary disease. Phys Ther 1990; 70: 439-442.

107. Stevens D, Elpern E, Sharma K, Szidon P, Ankin M, Kesten S. Comparison of hallway and treadmill Six-minute walk tests. Am J Respir Crit Care Med 1999; 160: 1540-1543.

108. Elazzazi A, Chapman N, Murphy E, White R. Measurement of distance walked and physiologic responses to a 6-minute walk test on level ground and on a treadmill: a comparative study. J Geriatr Phys Ther 2012; 35: 2-7. doi: 10.1519/ JPT.0b013e31821c91b1.

109. Janaudis-Ferreira T, Sundelin G, Wadell K. Comparison of the 6-minute walk distance test performed on a non-motorised treadmill and in a corridor in healthy elderly subjects. Physiotherapy 2010; 96: 234-239. doi: 10.1016/j.physio.2009.11.015.

110. Cutaia M, Brehm R, Cohen M. The relationship of the BODE index to oxygen saturation during daily activities in patients with chronic obstructive pulmonary disease. Lung 2011; 189: 269-277. doi: 10.1007/s00408-011-9308-1

111. Takigawa N, Tada A, Soda R et al. Distance and oxygen desaturation in $6-$ min walk test predict prognosis in COPD patients. Respir Med 2007; 101: 561-567.

112. Mak VH, Bugler JR, Roberts CM, Spiro SG. Effect of arterial oxygen desaturation on six minute walk distance, perceived effort, and perceived breathlessness in patients with airflow limitation. Thorax 1993; 48: 33-38.

113. Chuang ML, Lin IFD, Chen SP. Kinetics of changes in oxyhemoglobin saturation during walking and cycling tests in COPD. Respir Care 2014; 59: 353-362. doi: 10.4187/respcare.02494.

114. Chuang ML, Lin IF, Wasserman K. The body weight-walking distance product as related to lung function, anaerobic threshold and peak VO2 in COPD patients. Respir Med 2001; 95: 618-626.

115. Haynes JM. The ear as an alternative site for a pulse oximeter finger clip sensor. Respir Care 2007; 52: 727-729.

116. Clayton DG, Webb RK, Ralston AC, Duthie D, Runciman WB. Pulse oximeter probes. A comparison between finger, nose ear and forehead probes under conditions of poor perfusion. Anaesthesia 1991; 46: 260-265.

117. Barthelemy JC, Geyssant A, Riffat J, Antoniadis A, Berruyer J, Lacour JR. Accuracy of pulse oximetry during moderate exercise: a comparative study. Scand J Clin Lab Invest 1990; 50: $533-539$.

118. Hannhart B, Haberer J, Saunier C,Laxenaire MC. Accuracy and precision of fourteen pulse oximeters. Eur Respir J 1991; 4: $115-119$. 
119. Jensen LA, Onyskiw JE, Prasad NG. Meta-analysis of arterial oxygen saturation monitoring by pulse oximetry in adults. Heart Lung 1998; 27 : 387-408.

120. Muñoz X, Torres F, Sampol G et al. Accuracy and reliability of pulse oximetry at different arterial carbon dioxide pressure levels. Eur Respir J 2008; 32: 1053-1059. doi: 10.1183/09031936.00126507.

121. Mengelkoch LJ, Martin D, Lawler J. A review of the principles of pulse oximetry and accuracy of pulse oximeter estimates during exercise. Phys Ther 1994; 74: 40-49.

122. Beekman E, Mesters I, Hendriks E.J et al. Course length of 30 metres versus 10 metres has a significant influence on Six-minute walk distance in patients with COPD: an experimental crossover study. J Physiother 2013; 59: 169-176. doi: 10.1016/S1836-9553(13)70181-4.

123. Barrios JA, Crenshaw JR, Royer TD, Davis IS. Walking shoes and laterally wedged orthoses in the clinical management of medial tibiofemoral osteoarthritis: a one-year prospective controlled trial. Knee 2009; 16: 136-42. doi: 10.1016/j. knee.2008.10.002.

124. Jenkins SC. 6-minute walk test in patients with COPD: clinical applications in pulmonary rehabilitation. Physiotherapy 2007; 93: 175-182.

125. Rasekaba T, Lee AL, Naughton MT, Williams TJ, Holland AE. The Six-minute walk test: a useful metric for the cardiopulmonary patient. Intern Med J 2009; 39: 495-501. doi: 10.1111/j.1445-5994.2008.01880.x.

126. Guazzi M, Dickstein K, Vicenzi M, Arena R. 6 minute walk test and cardiopulmonary exercise testing in chronic heart failure: a comparative analysis on clinical and prognostic insights. Circ Heart Fail 2009; 2: 549-55. doi: 10.1161/CIRCHEARTFAILURE.109.881326.

127. Marciniuk DD, Butcher SJ, Reid JK et al. The effects of helium-hyperoxia on 6min walking distance in COPD: a randomized, controlled trial. Chest 2007; 131: 1659-1665.

128. Swinburn CR, Wakefield JM, Jones PW. Performance, ventilation, and oxygen consumption in three different types of exercise test in patients with chronic obstructive lung disease. Thorax 1985; 40: 581-586.

129. Leach RM, Davidson AC, Chinn S, Twort CH, Cameron IR, Bateman NT. Portable liquid oxygen and exercise ability in severe respiratory disability. Thorax 1992; 47: 781-789.

130. Guyatt GH, Pugsley SO, Sullivan MJ et al. Effect of encouragement on walking test performance. Thorax 1984; 39: $818-822$.

131. Gibbons WJ, Fruchter N, Sloan S, Levy RD. Reference values for a multiple repetition 6-minute walk test in healthy adults older than 20 years. J Cardiopulm Rehabil 2001; 21: 87-93.

132. Prusak J, Tomalak W. Wartości należne dla testu 6-minutowego chodu dla dzieci i młodzieży w wieku 7-18 lat. Acta Pneumonologica et Allergologica Pediatrica 2004; 7: 23-27.

133. Kempny A, Dimopoulos K, Alonso-Gonzalez R et al. Six-minute walk test distance and resting oxygen saturations but not functional class predict outcome in adult patients with Eisenmenger syndrome. Int J Cardiol 2013; 168: 4784-4789. doi: 10.1016/j.ijcard.2013.07.227..

134. Rostagno C, Olivo G, Comeglio M et al. Prognostic value of 6 -minute walk corridor test in patients with mild to moderate heart failure: comparison with other methods of functional evaluation. Eur J Heart Fail 2003; 5: 247-252.

135. Kawut SM, O'shea MK, Bartels MN, Wilt JS, Sonett JR, Arcasoy SM. Exercise testing determines survival in patients with diffuse parenchymal lung disease evaluated for lung transplantation. Respir Med 2005; 99: 1431-1439.

136. Dempsey JA, Wagner PD. Exercise-induced arterial hypoxemia. J Appl Physiol 1999; 87: 1997-2006.

137. Garvey C, Tiep B, Carter R, Barnett M, Hart M, Casaburi R. Severe exercise-induced hypoxemia. Respir Care 2012; 57 1154-1160. doi: 10.4187/respcare.01469.

138. Casanova C, Cote C, Marin JM et al. Distance and oxygen desaturation during the 6-min walk test as predictors of long-term mortality in patients with COPD. Chest 2008; 134: 746-752. doi: 10.1378/chest.08-0520.

139. Lama VN, Flaherty KR, Toews GB et al. Prognostic value of desaturation during a 6-minute walk test in idiopathic interstitial pneumonia. Am J Respir Crit Care Med 2003; 168: 1084-1090.

140. Redelmeier DA, Bayoumi AM, Goldstein RS, Guyatt GH. Interpreting small differences in functional status: the Six Minute Walk test in chronic lung disease patients. Am J Respir Crit Care Med 1997; 155: 1278-1282.

141. Puhan MA, Chandra D, Mosenifar Z et al. The minimal important difference of exercise tests in severe COPD. Eur Respir J 2011; 37: 784-790. doi: 10.1183/09031936.00063810.

142. Wise RA, Brown CD. Minimal clinically important differences in the Six-minute walk test and the incremental shuttle walking test. COPD 2005; 2: 125-129.

143. Puhan MA, Mador MJ, Held U, Goldstein R, Guyatt GH, Schünemann HJ. Interpretation of treatment changes in 6-minute walk distance in patients with COPD. Eur Respir J 2008; 32: 637-643. doi: 10.1183/09031936.00140507.

144. O'Keeffe ST, Lye M, Donnellan C, Carmichael DN. Reproducibility and responsiveness of quality of life assessment and six minute walk test in elderly heart failure patients. Heart (British Cardiac Society) 1998; 80: 377-382.

145. Gilbert C, Brown MC, Cappelleri JC, Carlsson M, McKenna SP. Estimating a minimally important difference in pulmonary arterial hypertension following treatment with sildenafil. Chest 2009; 135: 137-142. doi: 10.1378/chest.07-0275.

146. Du Bois RM, Weycker D, Albera C et al. Six-minute-walk test in idiopathic pulmonary fibrosis test validation and minimal clinically important difference. Am J Respir Crit Care Med 2011; 183: 1231-1237. doi: 10.1164/rccm.201007-1179OC.

147. Leggett RJ, Flenley DC. Portable oxygen and exercise tolerance in patients with chronic hypoxic cor pulmonale. Br Med J 1977; 2: 84-86.

148. Lacasse Y, Goldstein R, Lasserson TJ, Martin S. Pulmonary rehabilitation for chronic obstructive pulmonary disease. Cochrane Database Syst Rev 2006(4): Cd003793.

149. Tiong LU, Davies R, Gibson PG et al. Lung volume reduction surgery for diffuse emphysema. Cochrane Database Syst Rev 2006(4): Cd001001.

150. Bellet RN, Adams L, Morris NR. The 6-minute walk test in outpatient cardiac rehabilitation: validity, reliability and responsiveness - a systematic review. Physiotherapy 2012; 98: 277-286. doi: 10.1016/j.physio.2011.11.003. 


\section{Appendix 1}

Study protocol

6 minute walk test 30 meter corridor

\begin{tabular}{|c|c|c|c|}
\hline Name & \multicolumn{2}{|c|}{ ID No } & Date \\
\hline Age & $\begin{array}{c}\text { Body weight } \\
(\mathrm{kg})\end{array}$ & $\begin{array}{c}\text { Height } \\
\text { (cm) }\end{array}$ & $\begin{array}{c}\text { Protocol } \\
\text { No }\end{array}$ \\
\hline Indication & & & \\
\hline Start time: & & & \\
\hline Comments: & & \\
\hline
\end{tabular}

\begin{tabular}{|c|l|l|}
\hline & start & end \\
\hline $\mathrm{HR}$ & & \\
\hline $\mathrm{RR}$ & & \\
\hline $\mathrm{SpO}_{2}$ & & \\
\hline Dyspnea & & \\
\hline Distance & & \\
\hline Laps & \\
Stops: \\
$\mathbf{1}$-duration s, reason: \\
2-duration s, reason: \\
3-duration s, reason: \\
4-duration s, reason: \\
5-duration s, reason:
\end{tabular}

\section{Appendix 2}

Referral for the 6 minute walk test and patient consent form

\section{REFERRAL FOR THE 6 MINUTE WALK TEST}

Institution: ..tel.

Patient name: Age:

ID No: Case history No:

Indication for 6MWT:

\section{Concomitant diseases:}

1. None

2. Concomitant diseases which may influence the course of the test (musculoskeletal disorders in particular)

\section{DECLARE NO CONTRAINDICATIONS FOR THE 6 MINUTE WALK TEST.}

Date and signature of the referring physician

Attention: Information for the patient and the consent form are on the reverse page

INFORMATION for the patient

The aim of the study is to walk the longest distance possible during 6 minutes. You will be walking along the corridor between two marked points. During the test you may slow down or stop if necessary but you should continue walking as soon as you can, so that the distance walked in 6 minutes will be as long as possible. The technician will inform you about the time from the start of the test and about the time left to the end. Directly before and immediately after the test your blood pressure, heart rate and oxygen saturation with a finger sensor will be measured. You will also be asked to evaluate your dyspnea in a 10-point scale.

The distance walked in 6 minutes expressed in meters is the result of the test.

\section{PATIENT CONSENT FORM}

I, have read and understood the above information on the test, had the opportunity to ask additional questions, understood and accepted the given answers. I agree to perform the test and give my consent for storing my personal data. 


\section{Appendix 3}

\section{INFORMATION FOR THE PATIENT}

The aim of the test is to walk as far as possible for 6 minutes. You will be asked to walk back and forth along this corridor. The exercise you will perform during these six minutes is intensive, therefore you may feel short of breath or tired. You may slow down or even stop and lean against the wall to rest if necessary, but please resume walking as soon as you can.

Are you ready to start? Once you start, the counter will be turned on and you will hear it click with every turn, this will be noted on the worksheet. Remember that you are supposed to walk as fast as possible for 6 minutes, so do not jog or run.

You may start, when you are ready.

\section{Appendix 4}

\section{Encouragement}

- only the standardized encouragement phrases presented below should be used

- an even tone during motivation is recommended

- the technician should not talk to the patient or to the potential observers during the test

First minute:

You are doing very well. There are 5 minutes left.

\section{Second minute:}

Your pace is very good. You have 4 more minutes to go.

Third minute:

You are doing good. Half of this test is done.

Fourth minute:

Your pace is very good. There are only 2 minutes left .

Fifth minute:

Keep on walking like this. There is only one minute to go.

$15 \mathrm{~s}$ to the end of the test:

You will be asked to stop in a few moments. When you stop, please wait for me at the point you finished the test.

If the patient stops during the test:

Please rest, you may lean against the wall, if you need to. Continue walking as soon as you are able to.

\section{Appendix 5}

\section{Borg dyspnea scale}

0 nothing at all

1. very, very slight

2. very slight

3. slight

4. moderate

5. somewhat severe

6. severe

7. very severe

8.

9. very, very severe

10. maximal 